\title{
Characteristics and Drug Responses of Cochlear and Vestibular Adenylate Cyclase***
}

\author{
Dan Bagger-Sjöbäck ${ }^{1}$, Carol S. Filipek, and Jochen Schacht
}

Kresge Hearing Research Institute, University of Michigan,

Ann Arbor, MI 48109, USA

\section{Merkmale und Drogenreaktion von cochlearer und vestibulärer Adenylatzyklase}

Zusammenfassung. Die Aktivitäten von Adenylatzyklase in isolierten cochlearen und vestibulären Strukturen wurden in Inkubationen mit dem ATP-Analog Adenylylimidodiphosphat gemessen. Hohe Aktivitäten (pro mg protein) fanden sich in Stria vascularis und vestibulären Präparationen, geringere Aktivitäten im Ligamentum spirale, dem 8. Nerven und Cortischem Organ. In allen Präparationen wurde die Enzymaktivität stimuliert durch Fluorid, Guanylylimidodiphosphat oder Mangan(II)ionen und gehemmt durch Ethakrynsäure und Bleiionen. Das ototoxische Zytostatikum cis-Diammin-dichloroplatin hemmte die Zyklase von Stria vascularis signifikant.

Schlïsselwörter: Adenylatzyklase in vitro - Labyrinth-Strukturen - Aktivatoren - Ototoxische Zytostatika - Metallionen

Summary. Adenylate cyclase activity of dissected cochlear and vestibular structures was assayed with the ATP-analog adenylyl imidodiphosphate as substrate. High activities (per mg protein) were found in stria vascularis and in vestibular preparations, lower activities in spiral ligament, VIIIth nerve, and organ of Corti. The enzyme from all structures was stimulated by fluoride, guanylyl imidodiphosphate or manganese(II) ions, and strongly inhibited by ethacrynate and lead ion. The anti-cancer drug cis-diammine-dichloro platinum significantly inhibited adenylate cyclase from stria vascularis.

Key words: Adenylate cyclase in vitro - Labyrinthine structures - Activators Ototoxic drugs - Metal ions

* This work was supported by grant NS 12881 from the National Institutes of Health

** Presented at the 16th Workshop of Inner Ear Biology in Bern 1979

1 Permanent address: Department of Otolaryngology, Karolinska Sjukhuset, Stockholm, Sweden offprint requests to: Dr. Jochen Schacht (address see above) 
The membrane-bound enzyme adenylate cyclase mediates cellular responses to hormones in the systemic circulation, and to locally secreted agents, such as neurotransmitters. These extracellular "messengers" bind to receptors on the exterior surface of the cell plasma membrane activating the enzyme and thereby increasing formation of cyclic AMP. The latter is released intracellularly as "second messenger", regulating a broad spectrum of physiological responses.

The biochemical assay of adenylate cyclase is based on the determination of cyclic AMP (e.g., by radioimmunoassay) formed in the reaction

ATP $\rightarrow$ cyclic AMP + pyrophosphate.

Since ATPases, which are also present in tissue homogenates, rapidly deplete ATP in such incubations, an enzymatic system for the regeneration of ATP has to be supplied. The ATP analog, adenylyl imidodiphosphate (AMP-PNP), however, is a specific substrate for adenyl cyclase (Rodbell et al. 1971). The enzyme shows similar kinetic behavior with ATP and AMP-PNP but the imido linkage of the latter renders the terminal phosphate resistant to cleavage by other ATP-hydrolyzing enzymes (Yount 1975).

The presence of adenylate cyclase in cochlear tissues (Kerr and Schacht 1975; Ahlström et al. 1975) and the saccule (Paloheimo and Thalmann 1977) has been reported previously. We wish to present here some characteristics and comparative drug studies of cochlear and vestibular adenylate cyclase in assays with AMP-PNP.

\section{Methods}

\section{Dissections}

Inner ear structures from albino guinea pigs were isolated by microdissection in ice-cold $0.32 \mathrm{M}$ sucrose buffered with $1 \mathrm{mM} 2$-amino-2-methyl-1-propanol, $\mathrm{pH}$ 7.5. The entire cochlear duct was dissected, and the lateral wall was separated from the basilar membrane by a division through the Claudius cell region. From the vestibular system, the three ampullae of the semicircular canals were dissected as well as the macula of the utricle. The otoconia were removed from the latter. Tissues were carefully homogenized by hand in sucrose medium using glass tubes and pestles. Protein determination (Lowry et al. 1951) was adapted for small volumes.

\section{Enzyme Assay}

The incubation medium was slightly modified after Maguire and Gilman (1974) and consisted of $20 \mathrm{mM} 2-$ amino-2-methyl-1-propanol, $\mathrm{pH} 8.5,2 \mathrm{mM} \mathrm{MgCl}_{2}, 0.2 \mathrm{mM}$ isobutyl-methylxanthine, $10 \mu \mathrm{g}$ bovine serum albumine, and $0.5 \mathrm{mM}$ AMP-PNP, in a volume of $70 \mu 1$. Incubations were started by adding $30 \mu$ l of homogenate, except in studies of drug actions (Table 1) where AMP-PNP was added last after a pre-incubation of $5 \mathrm{~min}$. Reactions were terminated with $25 \mu \mathrm{l}$ of $10 \%$ trichloracetic acid, and the protein precipitate was removed by centrifugation. The supernatant was passed over a column of Dowex $50\left(\mathrm{H}^{+}\right)$and cyclic AMP eluted with distilled water (Steiner 1974). The eluted fractions were dried in a Speed Vac Concentrator (Savant, Hicksville, NY) and analysed by radioimmunoassay (Becton-Dickinson, Orangeburg, NY). All determinations were carried out at least in duplicate and a 0 -time blank was obtained for every incubation. 


\section{Results}

Adenylate cyclase was present in all structures investigated (Fig. 1). Assays were linear for both incubation time (Fig. 1) and amount of tissue used (Fig. 2) thus permitting valid comparisons between tissues. Activity was highest in stria vascularis, spiral ligament and the ampullae (0.8 pmol cyclic AMP formed $\times \min ^{-1} \times \mathrm{mg}^{-1}$ protein) and lower in the other preparations. Mostly, stria vascularis and spiral ligament were assayed in a combined preparation for ease of dissections. When separate activities were measured, adenylate cyclase in stria vascularis was about twice as high as in spiral ligament. Fluoride consistently stimulated enzymatic activity about 3-fold (Fig. 1).

The GTP-analog, guanylyl imidodiphosphate (GMP-PNP) enhanced enzymatic activity while the diuretic ethacrynic acid strongly inhibited adenylate cyclase in all tissues (Table 1). The effect of the anti-cancer drug cis-diammine-dichloroplatinum (cis-DDP) was less consistent. Preparations of nerve and vestibular tissues did not seem to repond to the drug, and organ of Corti showed a variable decrease of enzymatic activity $(20 \% \pm 23$ S.D., $n=9)$. A significant inhibition was seen in the tissues of the lateral wall $(60 \% \pm 20$ S.D., $n=7)$.

Manganese(II)ions greatly increased cyclic AMP formation (Table 2), and in three independent experiments the range of stimulation was 5 to 15 -fold. Strontium caused a small but reproducible decrease of enzymatic activity $(30 \% \pm 16$ S.D., $n=3)$. Lead

Fig. 1. Time course of cyclic AMP formation. Homogenates of inner ear tissues were incubated for the times indicated as described in "Methods". Open circles: controls, closed circles: $10 \mathrm{mM}$ $\mathrm{NaF}$ added. AMP: ampulla (21 $\mu \mathrm{g}$ protein per incubation), $\mathrm{OC}$ : organ of Corti and supporting cells $(31 \mu \mathrm{g}$ protein), N: cochlear division of VIIIthe nerve $(57 \mu \mathrm{g}$ protein). SV/SL: Stria vascularis and spiral ligament (37 $\mu \mathrm{g}$ protein). UTR: Maculae utriculi $(5 \mu \mathrm{g}$ protein). These amounts approximately correspond to recoveries from one ear (AMP, UTR, OC), two-thirds (SV/SL) and one half ear $(\mathrm{N})$

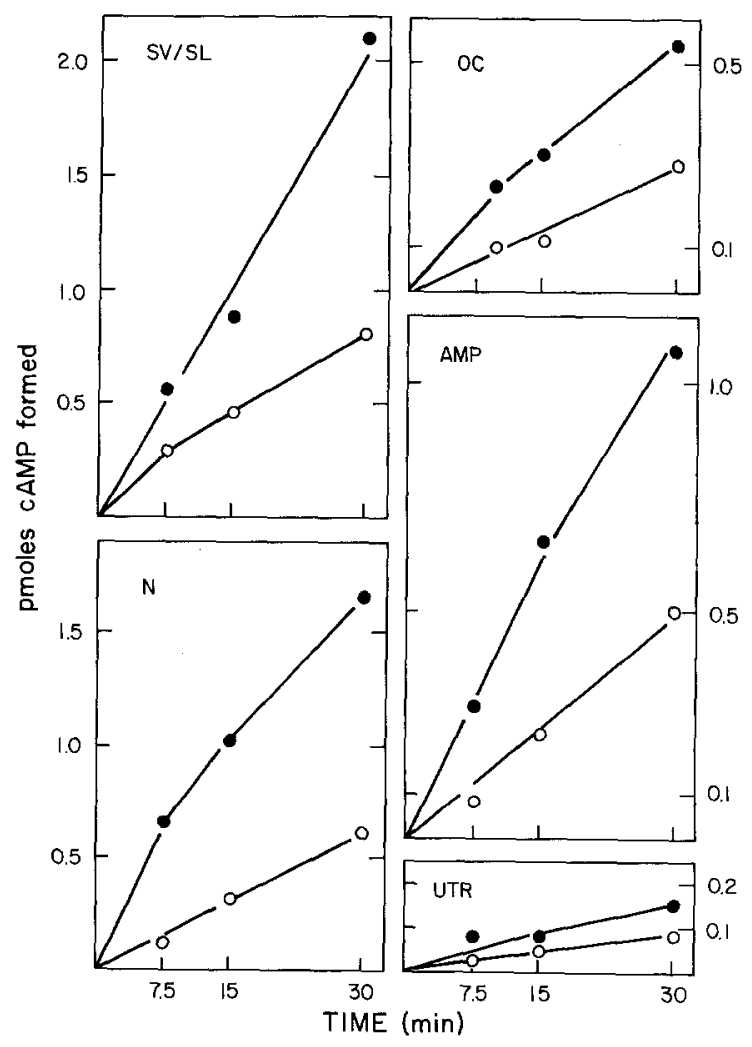




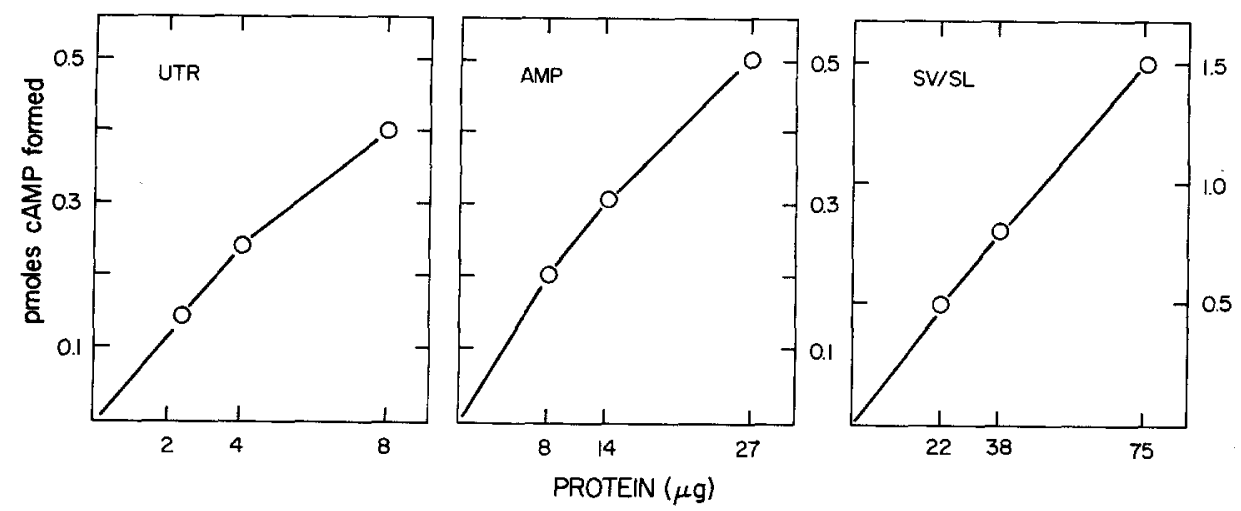

Fig. 2. Dependency of adenylate cyclase reaction on protein concentration. Varying amounts of homogenates were incubated for $20 \mathrm{~min}$ as described in "Methods". Tris-Cl was substituted for aminomethyl-propanol. Abbreviations as in Fig. 1

Table 1. Effect of drugs on inner ear adenylate cyclase

\begin{tabular}{lllll}
\hline Addition & OC & & SV/SL & AMP + UTR $N$ \\
\cline { 3 - 5 } & & & pmol cAMP formed $\times \mathrm{mg}^{-1}$ & protein $\times \mathrm{min}^{-1}$ \\
\hline None (control) & 0.20 & 0.30 & 0.18 & 0.13 \\
$50 \mu$ M GMP-PNP & $\mathrm{a}$ & 0.54 & 0.52 & 0.31 \\
$100 \mu$ M ethacrynate & 0.08 & 0.03 & 0.07 & 0.04 \\
$100 \mu$ M cis-DDP & 0.14 & 0.11 & 0.21 & 0.13 \\
\hline
\end{tabular}

Approximately $30-120 \mathrm{ug}$ protein was pre-incubated with the drugs for $5 \mathrm{~min}$ followed by a $30 \mathrm{~min}$ incubation as described in "Methods". Abbreviation of tissues, see legend to Fig. 1

${ }^{a}$ The effect of GMP-PNP was determined in a separate experiment: control, 0.41; with GMP-PNP, 0.67

Table 2. Effect of divalent cations on inner ear adenylate cyclase

\begin{tabular}{lll}
\hline Addition & Active tissue & Boiled tissue \\
\cline { 2 - 3 } & pmol cAMP formed/30 min \\
\hline None (control) & 2.5 & 0.0 \\
$4 \mathrm{mM} \mathrm{SrCl}$ & 1.3 & 0.2 \\
$4 \mathrm{mM} \mathrm{Pb}\left(\mathrm{NO}_{3}\right)_{2}$ & 7.9 & 7.3 \\
$4 \mathrm{mM} \mathrm{MnCl}$ & 9.5 & 0.0 \\
\hline
\end{tabular}

Incubations were carried out with $70 \mu \mathrm{g}$ cochlear protein $(\mathrm{OC}+\mathrm{SV} / \mathrm{SL}+\mathrm{N}$, defined in legend to Fig. 1$)$ as described in "Methods". "Boiled tissue" was heated in homogenization medium for $30 \mathrm{~min}$ at $100^{\circ} \mathrm{C}$ prior to the incubation 
apparently enhanced cyclic AMP production, mostly, however, by a non-enzymatic breakdown of the substrate as shown in incubations with inactivated tissue. The net effect is a strong inhibition of adenylate cyclase activity. Manganese and strontium ions did not have a significant effect on the incubation medium in the presence of inactivated tissue, nor did the drugs above.

\section{Discussion}

The importance of the adenylate cyclase/cyclic AMP system in the inner ear is speculative. The localization of the enzyme in various structures of this organ implies rather diversified roles for it. The observation that the ototoxic diuretic, ethacrynic acid, is an inhibitor of adenylate cyclase (Kerr and Schacht 1975; Thalmann et al. 1975) might implicate the enzyme in the regulation of cochlear fluids. Speculations for such a role are supported by evidence linking adenylate cyclase activity to electrolyte and water transport in the renal tubule, the epithelia of the intestine, stomach, and toad bladder, and the erythrocyte membrane (Strewler and Orloff 1977). Ethacrynic acid clearly inhibits adenylate cyclase in all inner ear tissues tested. It thus appears that discussions of this drug action may have to take multiple sites of action into consideration rather than a specific effect on one tissue, e.g., stria vascularis.

Adenylate cyclase may also be the target of other ototoxic drugs such as cis-DDP. This antineoplastic agent can cause hearing loss in humans (Piel et al. 1974) and cochlear damage in animals (Fleishman et al. 1975; Stadnicki et al. 1975). Although our results are still preliminary, an inhibition of adenylate cyclase of the lateral wall tissues is clearly evident. However, while AMP-PNP is advantageous for the comparison of adenylate cyclase activities without interference by ATPases, the $\mathrm{pH}$ of the incubation is higher than physiological $\mathrm{pH}$. This may interfere with actions of weakly basic drugs or hormones, and the effect of cis-DDP needs further evaluation.

The pattern of the response of cochlear adenylate cyclase to metal ions essentially follows that for the enzyme from brain (Walton and Baldessarini 1976). $\mathrm{Pb}^{++}$is strongly inhibitory while causing considerable non-enzymatic formation of cyclic AMP from AMP-PNP. $\mathrm{Mn}^{++}$is a powerful stimulator of cochlear adenylate cyclase and may thus hold promise as a tool to help elucidate the physiological function of this enzyme. $\mathrm{Sr}^{++}$has a small inhibitory action on the enzyme causing only little non-enzymatic breakdown of the substrate. We have previously suggested to replace $\mathrm{Pb}^{++}$in the cytochemical demonstration of adenylate cyclase by $\mathrm{Sr}^{++}$(Kerr and Schacht 1976) and this remains to be explored in more detail.

Our study provides new evidence for the presence of adenylate cyclase in tissues of the ampullae and Macula utriculi. This study then, and those by Thalmann's laboratory (Ahlström et al. 1975; Paloheimo and Thalmann 1977) provide a complete assessment of adenylate cyclase in labyrinthine structures. Although different assay conditions preclude direct comparison of data from the two laboratories it seems clear that highest activities (per mg dry weight or mg protein) are found in stria vascularis and vestibular structures, and low activities in preparations taken from the cochlear portion of the VIIIth nerve. The stimulatory effects of fluoride and GMP-PNP are consistent with the response of the enzyme from other sources and were also observed by Zenner and Zenner (1979) with cochlear adenylate cyclase. 
The elucidation of the physiological function of adenylate cyclase in the inner ear will require a combination of cytochemical, electrophysiological, and morphological investigations. One role of biochemical analyses, such as this is to define the effect of drugs and agents on the enzyme. Well defined inhibitors and activators may then serve as useful tools in further studies of the role of adenylate cyclase in the microhomeostasis of the inner ear.

\section{References}

Ahlström P, Thalmann I, Thalmann R, Ise I (1975) Cyclic AMP and adenylate cyclase in the inner ear. Laryngoscope $85: 1241-1258$

Fleischman RW, Stadnicki SW, Ethier MR, Schaeppi U (1975) Ototoxicity of cis-dichlorodiammine platinum (II) in the guinea pig. Toxicol Appl Pharmacol 33:320-332

Kerr TP, Schacht J (1975) Adenylate cyclase in the guinea pig cochlea. J Acoust Soc Am $57: S 61$

Kerr TP, Schacht J (1976) Cellular localization of adenylate cyclase in the guinea pig cochlea. Neurosci Abstr 2:22

Lowry OH, Rosebrough NJ, Farr AL, Randall RJ (1951) Protein measurement with the Folin phenol reagent. J Biol Chem 193:265-275

Maguire ME, Gilman AG (1974) Adenylate cyclase assay with adenylyl imidodiphosphate and product detcction by competitive protein binding. Biochem Biophys Acta 358:154-160

Paloheimo S, Thalmann R (1977) Influence of "loop" diuretics upon $\mathrm{Na}^{+}: \mathrm{K}^{+}$-ATPase and adenylate cyclase of the stria vascularis. Arch Otorhinolaryngol 217:347-359

Piel IJ, Meyer D, Perlia CP, Wolfe VI (1974) Effects of cis-diammine-dichloro platinum (nsc-119875) on hearing function in man. Cancer Chemother Rep 58:871-875

Rodbell M, Birnbaumer L, Pohl SL, Krans HM (1971) The glucagon-sensitive adenyl cyclase system in plasma membranes of rat livers. J Biol Chem 246:1877-1882

Stadnicki SW, Fleischman RW, Schaeppi U, Merriam P (1975) Cis-dichloro-diammino platinum(II) (nsc119875): hearing loss and other toxic effects in rhesus monkeys. Cancer Chemother Rep $59: 467-480$

Steiner AL (1974) Assay of cyclic nucleotides by radioimmunoassay methods. In: Harman JG, O'Malley BW (eds) Methods in enzymology, vol 38. Academic Press, New York, pp 96-105

Strewler GJ, Orloff J (1977) Role of cyclic nucleotides in the transport of water and electrolytes. Adv Cyc Nucl Res 8:311-316

Thalmann R, Ise I, Bohne BA, Thalmann I (1977) Actions of loop diuretics and mercurials upon the cochlea. Acta Otolaryngol 83:221-232

Walton KG, Baldessarini RJ(1976) Effects of $\mathrm{Mn}^{2+}$ and other divalent cations on adenylate cyclase activity in rat brain. J Neurochem 27:557-564

Yount RG (1975) ATP analogs. In: Meister A (ed) Advances in enzymology, vol 43. J. Wiley \& Sons, New York $\mathrm{p} 1$

Zenner H-P, Zenner B (1979) Vasopressin and isoproterenol activate adenylate cyclase in the guinea pig innner ear. Arch Otolaryngol 222:275-283

Received December 19, 1979/Accepted February 22, 1980 